
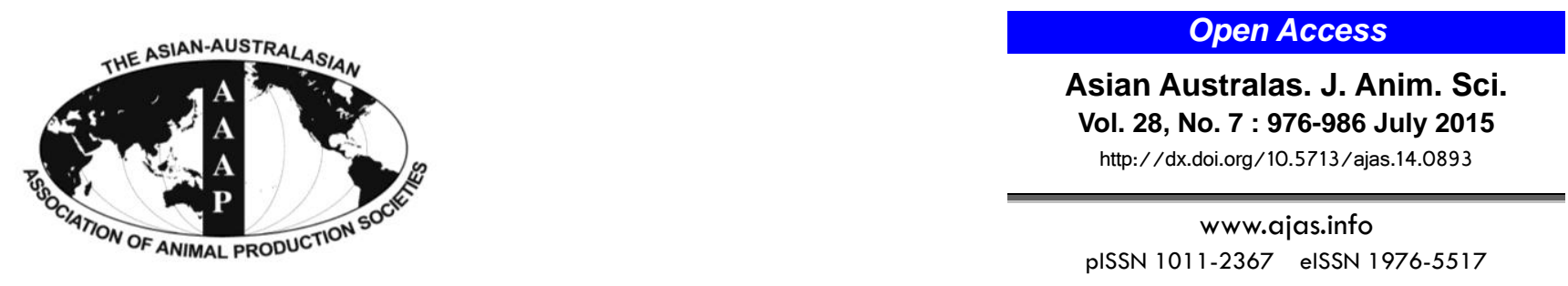

\title{
Lipid Sources with Different Fatty Acid Profile Alters the Fatty Acid Profile and Quality of Beef from Confined Nellore Steers
}

\author{
Giovani Fiorentini $^{1}{ }^{1 *}$, Josiane F. Lage ${ }^{1}$, Isabela P. C. Carvalho ${ }^{1}$, Juliana D. Messana ${ }^{1}$, \\ Roberta. C. Canesin ${ }^{1}$, Ricardo A. Reis ${ }^{1,2}$, and Telma T. Berchielli ${ }^{1,2}$ \\ ${ }^{1}$ Department of Animal Sciences, UNESP, Univ Estadual Paulista, Jaboticabal, SP 14884-900, Brazil
}

\begin{abstract}
The present study was conducted to determine the effects of lipid sources with different fatty acids profile on meat fatty acids profile and beef quality traits of Nellore. A total of 45 Nellore animals with an average initial body weight of $419 \pm 11 \mathrm{~kg}$ (at $15 \pm 2$ mo) were distributed in a completely randomized design consisting of 5 treatments and 9 replicates. The roughage feed was maize silage $(600 \mathrm{~g} / \mathrm{kg}$ on a dry matter [DM] basis) plus concentrate (400 g/kg on a DM basis). The dietary treatments were as follows: without fat (WF), palm oil (PO), linseed oil (LO), protected fat (PF), and soybean grains (SG). No effects of lipid sources were observed (p>0.05) on beef color, $\mathrm{pH}$, water-holding capacity, and sarcomere length. Beef from cattle fed PO had greater shear-force values $(\mathrm{p}<0.05)$ compared to beef from cattle fed WF. Deposition of main unsaturated fatty acids (oleic, linoleic, and linolenic) was greater in treatments WF, SG, and LO, respectively, while the values of conjugated linoleic acid (CLA) were greater when animals were fed LO. The inclusion of LO in the diet enhances the concentration of CLA in longissimus muscle and subcutaneous fat besides improving the atherogenicity index and elongase activity. As such, LO can be used with the aim to improve the quality of beef from confined Nellore cattle. Conversely, the use of PO is not recommended since it may increase the concentration of undesirable unsaturated fatty acids in muscle and subcutaneous fat, shear-force and the atherogenicity index. (Key Words: Conjugated Linoleic Acid, Linseed Oil, Palm Oil, Protected Fat, Soybean Grain, Steers)
\end{abstract}

\section{INTRODUCTION}

Modification of the fatty acids profile of meat to obtain a lower proportion of saturated fatty acids (SFA) is a reliable method to produce a healthier meat for consumers (Ladeira et al., 2014). One of the main strategies to improve the quality of final products of ruminant animals (milk and meat) is the ruminal manipulation with addition of lipid sources (Daley et al., 2010; Moloney et al., 2012). Feedstuff with different fatty acids profile may be used as lipid sources in diets of ruminant animals (Fiorentini et al., 2012; Oliveira et al., 2012; Ladeira et al., 2014). However a limitation for the deposition of unsaturated fatty acids (UFA) in the meat and dairy products of ruminants occurs

\footnotetext{
* Corresponding Author: Giovani Fiorentini. Tel: +55-16-32092682, E-mail: giovanizoot@yahoo.com.br

${ }^{2}$ Department of Animal Sciences, Universidade Federal deViçosa, INCT/CA, Viçosa, MG 36570-000, Brazil.

Submitted Nov. 25, 2014; Revised Jan. 20, 2015; Accepted Feb. 10, 2015
}

due to ruminal biohydrogenation of UFA (Herdmann et al., 2010). According to Allen (2000), the biohydrogenation process is enhanced (up to 90\%) and animals are fed diets containing oil as a lipid source.

An important lipid source is the rumen protected fat (PF) from soybean oil, which exhibit low fatty acid release in the rumen (Jenkins and Bridges, 2007), and may result in increased monounsaturated fatty acids (MUFA) deposition in meat. Oleaginous seeds such as soybean grains are also a potential source of slow release oil in the ruminal environment. Thus, the use of these sources may be a nutritional strategy that increases the ruminal escape of UFA (Duckett and Gillis, 2010), reducing the deposition of saturated fatty acids and enhancing the levels of UFA in animal tissues.

However, a limited number of studies have shown the effects of different dietary lipid sources on fatty acids profile and quality traits of meat from Zebu cattle during the finishing period. As such, the present study aimed to 
evaluate the qualitative traits, composition and quality of fatty acids of meat and subcutaneous fat from Nellore steers fed lipid sources with different fatty acids profile.

\section{MATERIALS AND METHODS}

The protocol used in this experiment was in accordance with the Brazilian College of Animal Experimentation (Colégio Brasileiro de Experimentação Animal, COBEA) guidelines and was approved by the Ethics, Bioethics, and Animal Welfare Committee (Comissão de Ética e Bem Estar Animal, CEBEA) of the FCAV, UNESP, Jaboticabal campus (protocol number 012799).

\section{Animals and feeding}

A total of 45 Nellore steers (initial body weight $=$ $419 \pm 11 \mathrm{~kg} ; 15 \pm 2 \mathrm{mo})$ were housed in individual $8 \mathrm{~m}^{2}(4 \times 2$ $\mathrm{m})$ pens that were provided with a concrete trough and drinker. The animals spent $28 \mathrm{~d}$ acclimating to the diets, facilities, and management. After this period, they were confined for $90 \mathrm{~d}$ (experimental period).

The feeds were formulated to be isonitrogenous according to the NRC (2000). Five concentrates were formulated: i) without additional fat (WF; $27.9 \mathrm{~g} / \mathrm{kg}$ of ether extract $[\mathrm{EE}]$ in the total diet); ii) with palm oil (PO) derived from the palmaceae plant Orbignya oleifera, which has a lipid profile rich in medium-chain fatty acids (lauristic and myristic); iii) with linseed oil (LO); iv) with PF, Lactoplus Dalquim group, Itajaí, Santa Catarina, Brazil; and v) with soybeans grains (SG). All the diets with added lipids contained an average of $42 \mathrm{~g}$ of additional lipid per $\mathrm{kg}$ of dry matter (DM).

The roughage was corn silage $(600 \mathrm{~g} / \mathrm{kg}$ on a DM basis and with the following composition: $369 \mathrm{~g} \mathrm{DM} / \mathrm{kg}, 71 \mathrm{~g}$ crude protein $/ \mathrm{kg} \mathrm{DM}, 477 \mathrm{~g}$ neutral detergent fiber/kg DM, $23 \mathrm{~g} \mathrm{EE} / \mathrm{kg} \mathrm{DM}$, and $53 \mathrm{~g}$ lignin/kg DM) and concentrate (400 g/kg on a DM basis). The concentrates were mixed weekly to restrict oxidation and rancidity of ingredients. The lipid sources (PO, LO, PF, and SG) were incorporated into the remaining ingredients of the concentrate in a horizontal mixer for $15 \mathrm{~min}$. The proportions of ingredients and the chemical composition of the experimental diets are presented in Table 1. The animals were fed with corn silage and the experimental concentrates once a day at 08:00 $\mathrm{h}$ as a total mixed ration. Throughout the entire experimental period, the provided quantities were adjusted to allow a surplus of approximately $100 \mathrm{~g} / \mathrm{kg}$ in relation to the total amount consumed on the previous day.

\section{Chemical analyses of feedstuff}

Samples of corn silage and concentrates were analyzed to determine DM (method 934.01) and mineral matter (method 942.05) and to obtain an acid EE (method 954.02) according to AOAC (1990). Nitrogen was determined using an LECO FP-528 nitrogen analyzer (LECO Corp., St. Joseph, MI, USA). Neutral detergent fiber was determined using $\alpha$-amylase and without the addition of sodium sulfite following Van Soest et al. (1991) and adapted for the Ankom $^{200}$ Fiber Analyzer (Ankom Technology, Fairport, NY, USA). Acid detergent fiber was determined using the method described by Goering and Van Soest (1970) and adapted for the Ankom ${ }^{200}$ Fiber Analyzer (Ankom Technology, USA).

To determine the fatty acid composition of feed offerings, a sample of approximately $1 \mathrm{~g}$ was used. The frozen sample was homogenized in $20 \mathrm{~mL}$ of a chloroform and methanol solution $(2: 1)$ using a Turrax homogenizer, disintegrator, and emulsifier (Folch et al., 1957). In the next step, the lipid extract aliquot was methylated using the protocol in Kramer et al. (1997). Fatty acids were quantified using a GC 2010 gas chromatograph (Shimadzu Corp., Kyoto, Japan) with an SP-2560 capillary column (100 $\mathrm{m} \times 0.20 \mathrm{~mm}$ i.d. with a $0.02-\mu \mathrm{m}$ film thickness; Supelco, Bellefonte, PA, USA). The initial temperature was set to $70^{\circ} \mathrm{C}$ for $4 \mathrm{~min}\left(13^{\circ} \mathrm{C} / \mathrm{min}\right)$ until it reached $175^{\circ} \mathrm{C}$ and then held for $27 \mathrm{~min}$. After this, the temperature was increased $4^{\circ} \mathrm{C} / \mathrm{min}$ until it reached $215^{\circ} \mathrm{C}$ and was held there for 31 min. Hydrogen was used as the carrier gas with a flow of 40 $\mathrm{cm}^{3} / \mathrm{s}$ (Table 1).

\section{Slaughter, carcass data collection and meat sampling}

At the end of the experimental period cattle were transported to a commercial beef slaughterhouse and slaughtered at the same day. Pre-harvest handling was in accordance with good animal welfare practices, and slaughtering procedures followed the Sanitary and Industrial Inspection Regulation for Animal Origin Products. After the slaughter carcasses were chilled for 24 hours in cold chamber. After the chilling period meat samples were collected though a perpendicular cut in the longissimus muscle between the 12th and 13th ribs the right half of the carcass. Longissimus muscle samples were individually vacuum-packaged and held at $-20^{\circ} \mathrm{C}$ for 2 days. Each frozen longissimus sample was standardized from the posterior end into one $2.54 \mathrm{~cm}$ thick steak sample (AMSA, $1995)$ for Warner-Bratzler shear force measurement and two $1 \mathrm{~cm}$ thick steaks for further analysis. All steaks were vacuum packaged and held at $-20^{\circ} \mathrm{C}$ for 10 days until the analysis were performed.

\section{Meat and subcutaneous fat instrumental color analysis}

Meat and fat instrumental color analysis was performed as described by Houben et al. (2000) using a Minolta colorimeter (Model CR 300, Minolta Camera Co. Ltd., Osaka, Japan) to evaluate lightness $\left(L^{*}\right)$, redness $\left(a^{*}\right)$, and yellowness $\left(b^{*}\right)$. The color aspects were assessed by the 
Table 1. Composition of the experimental diets ( $\mathrm{g} / \mathrm{kg}$ on a DM basis)

\begin{tabular}{|c|c|c|c|c|c|}
\hline & \multicolumn{5}{|c|}{ Diets } \\
\hline & WF & $\mathrm{PO}$ & $\mathrm{LO}$ & $\mathrm{PF}$ & WS \\
\hline \multicolumn{6}{|l|}{ Ingredient } \\
\hline Corn silage & 600 & 600 & 600 & 600 & 600 \\
\hline Ground corn & 269 & 214 & 214 & 208 & 138 \\
\hline Soybean meal & 110 & 120 & 120 & 121 & 0.00 \\
\hline Protected fat & 0.00 & 0.00 & 0.00 & 51.0 & 0.00 \\
\hline Whole soybean & 0.00 & 0.00 & 0.00 & 0.00 & 250 \\
\hline Linseed oil & 0.00 & 0.00 & 45.0 & 0.00 & 0.00 \\
\hline Palm oil & 0.00 & 45.0 & 0.00 & 0.00 & 0.00 \\
\hline Urea & 9.00 & 9.00 & 9.00 & 9.00 & 0.00 \\
\hline Mineral suplement ${ }^{1}$ & 12.0 & 12.0 & 12.0 & 12.0 & 12.0 \\
\hline \multicolumn{6}{|l|}{ Chemical composition } \\
\hline $\mathrm{DM}$ & 562 & 569 & 568 & 563 & 563 \\
\hline $\mathrm{OM}$ & 954 & 955 & 956 & 945 & 954 \\
\hline $\mathrm{CP}$ & 160 & 160 & 161 & 164 & 164 \\
\hline Ether extract & 27.9 & 70.5 & 70.2 & 69.9 & 69.7 \\
\hline NDF & 340 & 340 & 340 & 339 & 364 \\
\hline $\mathrm{ADF}$ & 195 & 196 & 198 & 196 & 220 \\
\hline $\mathrm{GE}(\mathrm{MJ} / \mathrm{kg})$ & 1.04 & 1.15 & 1.14 & 1.14 & 1.16 \\
\hline $\mathrm{TDN}^{2}$ & 719 & 841 & 840 & 845 & 838 \\
\hline \multicolumn{6}{|c|}{ Fatty acids, $g / 100 \mathrm{~g}$ of total fatty acids } \\
\hline C8:0 (caprylic) & 0.00 & 0.90 & 0.00 & 0.00 & 0.00 \\
\hline C10:0 (capric) & 0.00 & 1.00 & 0.00 & 0.00 & 0.00 \\
\hline C12:0 (lauric) & 0.40 & 15.7 & 0.70 & 0.30 & 0.30 \\
\hline C14:0 (myristic) & 0.40 & 5.40 & 0.50 & 0.40 & 0.40 \\
\hline C16:0 (palmitic) & 19.7 & 16.6 & 18.7 & 19.0 & 17.5 \\
\hline C16:1 (palmitoleic) & 0.10 & 0.10 & 0.10 & 0.10 & 0.10 \\
\hline C17:0 (margaric) & 0.20 & 0.20 & 0.20 & 0.20 & 0.20 \\
\hline C18:0 (stearic) & 1.90 & 0.50 & 3.80 & 0.00 & 1.30 \\
\hline C18:1n-9,c (oleic) & 30.5 & 24.6 & 28.6 & 29.9 & 27.3 \\
\hline C18:2n-6,c (linoleic) & 43.3 & 31.8 & 36.3 & 45.9 & 46.3 \\
\hline C20:0 (arachidic) & 0.00 & 0.00 & 0.10 & 0.00 & 2.60 \\
\hline C18:3n-6 (linolenic) & 2.80 & 2.80 & 11.2 & 4.40 & 4.10 \\
\hline
\end{tabular}

DM, dry matter; WF, without additional fat; PO, palm oil; LO, linseed oil; PF, protected fat (LactoPlus); WS, whole soybean; OM, organic matter; CP, crude protein; NDF, neutral detergent fiber; ADF, acid detergent fiber; GE, gross energy; TDN, total digestible nutrients.

${ }^{1}$ Composition of product expressed in g or mg per $100 \mathrm{~g}$ of supplement: Calcium, $4.5 \mathrm{~g}$; Phosphorus, 1.2; Magnesium, $4.6 \mathrm{~g}$; Sulfur, $1.4 \mathrm{~g}$; Sodium, 5.8; Copper, $14 \mathrm{mg}$; Manganese, $41 \mathrm{mg}$; Zinc, $52.5 \mathrm{mg}$; Iodine, $1 \mathrm{mg}$; Cobalt, $0.8 \mathrm{mg}$; Selenium, $0.3 \mathrm{mg}$; Fluorine (Maximun), $12 \mathrm{mg}$.

${ }^{2}$ Total digestible nutrients by NRC, 2001.

Commission Internationale de l'Eclairage $L * a * b *$ color system using $0^{\circ} / 45^{\circ}$. Samples of meat and subcutaneous fat were allowed to bloom for $30 \mathrm{~min}$ prior the color evaluation. After this step objective color was measured at 3 locations on the displayed surface of each steak and the average values of $L^{*} a^{*} b^{*}$ were calculated. The colorimeter was calibrated according to the manufacturer before analyzing the samples.

The chroma $(\mathrm{C})$ and hue $(\mathrm{h})$ values were calculated as described by MacDougal (1994) by using the values of lightness $\left(L^{*}\right)$, redness $\left(a^{*}\right)$, and yellowness $\left(b^{*}\right)$ obtained from the color measurements as it follows:

$$
\mathrm{C}=\left[\left(\mathrm{a}^{*}\right)^{2}+(\mathrm{b} *)^{2}\right]^{0.5}
$$

$$
\mathrm{h}=\arctan (\mathrm{b} * / \mathrm{a} *)
$$

\section{Warner-Bratzler shear force measurement and cooking losses}

Warner-Bratzler shear force (WBSF) steaks were thawed at $4^{\circ} \mathrm{C}$ for $24 \mathrm{~h}$ and oven-broiled in an electric oven (Layr, Luxo, Inox) preheated to $150^{\circ} \mathrm{C}$. Internal steak temperatures were monitored by 20-gauge copperconstantan thermocouples (Omega Engineering, Stamford, CT, USA) placed in the approximate geometric center of each steak and attached to a digital monitor. When internal steak temperature reached $35^{\circ} \mathrm{C}$, the steak was turned over and allowed to reach an internal temperature of $70^{\circ} \mathrm{C}$ before removal from the oven. Cooked WBSF steaks were cooled for $24 \mathrm{~h}$ at $4^{\circ} \mathrm{C}$ (AMSA, 1995). Eight round cores $(1.27 \mathrm{~cm}$ 
diameter) were removed from each steak parallel to the long axis of the muscle fibers (AMSA, 1995). Each core was sheared once through the center, perpendicular to the fiber direction by a Warner-Bratzler shear machine (G-R Manufacturing Company, Manhattan, KS, USA). The cooking losses were evaluated on the steaks that were also used for WBSF measurement. Total cooking loss was calculated as the difference between the weight of the steaks before and after oven-broiling.

\section{Sarcomere length}

Longissimus muscle samples were collected at $24 \mathrm{~h}$ postmortem and small cubes $(3.0 \times 3.0 \times 2.0 \mathrm{~cm})$ were excised in triplicate from each sample. Cubes were then fixed as described by Koolmees et al. (1986). Sarcomere length was measured by laser diffraction using a 05-LHR-021 laser, Melles Griot (Carlsbad, CA, USA) and calculated as described by Cross et al. (1981). From each cube, sarcomere length of six fiber samples was determined and used for sarcomere length average calculation.

\section{Fatty acid profile}

To determine the fatty acid composition of the fresh meat samples the transversal section were collected from the longissimus muscle, freeze-dried, and frozen for lipid extraction and methylation. The fatty material was extracted using a mixture of chloroform-methanol as reported by Bligh and Dyer (1959) and the fatty acids methyl esters were obtained by ISO 5509 method (ISO 5509, 2000). Qualitative and quantitative measurements of fatty acid content were performed by gas chromatography using a chromatographer (Model GC-14B with a Communication Bus Module, CBM 102; Shimadzu, Kyoto, Japan) with a flame ionization detector and fused silica capillary column (Omegawax 250), which was $30 \mathrm{~m}$ length and $0.25 \mathrm{~mm}$ diameter and had a film thickness of $0.25 \mu \mathrm{m}$ (Supelco SP24136, USA). Helium was used as a carrier gas at a flow of $1 \mathrm{~mL} / \mathrm{min}$. A $1-\mu \mathrm{L}$ aliquot of the sample was injected into a "split" at a division ratio of $1 / 100$ and a temperature of $250^{\circ} \mathrm{C}$. The temperature of the oven was programmed to remain at $100^{\circ} \mathrm{C}$ for $2 \mathrm{~min}$ and then increased to $220^{\circ} \mathrm{C}$ at $4^{\circ} \mathrm{C} / \mathrm{min}$ for $25 \mathrm{~min}$, while the detector was at $280^{\circ} \mathrm{C}$. Identification and quantification of the methyl esters of the fatty acids was achieved by comparison with the retention times and concentrations of methyl esters of standard fatty acids.

The activity index were calculated for elongase and $\Delta^{9}$ desaturase enzymes on fatty acids with 16 and 18 carbons which are responsible for the conversion of SFA with 16 and 18 carbons into their respective correspondents monounsaturated with double bond in carbon 9 as described by MalauAduli et al. (1997). The atherogenecity index was calculated as described by Ulbricht and Southgate (1991) as an indicator of risk of cardiovascular disease. Calculations were performed as it follows:

$\Delta^{9}$-desaturase $\mathrm{C} 16$ activity

$=100[(16: 1$ cis-9)/16:1 cis-9+16:0)]

$\Delta^{9}$-desaturase $\mathrm{C} 18$ activity

$=100[(18: 1$ cis-9)/18:1 cis-9+18:0)]

\author{
Elongase activity \\ $=100[(\mathrm{C} 18: 0+\mathrm{C} 18: 1$ cis -9$)$ \\ $/(\mathrm{C} 16: 0+\mathrm{C} 16: 1$ cis-9+C18:0+C18:1 cis-9)]
}

\author{
Atherogenicity index \\ $=[\mathrm{C} 12: 0+4(\mathrm{C} 14: 0)+\mathrm{C} 16: 0]$ \\ $/(\Sigma \mathrm{SFA}+\Sigma$ polyunsaturated fatty acids $)$
}

\section{Statistical analysis}

The statistical analysis was conducted using the general linear model procedure of SAS (Statistical Analysis System, version 9.1) as the following model:

$$
\mathrm{Y}_{i j}=\mu+\mathrm{t}_{i}+\mathrm{e}_{i j}
$$

where $\mathrm{Y}_{i j}=$ observation of animal $j$ subject to treatment $i ; \mu=$ the overall mean; $\mathrm{t}_{i}=$ effect of treatment $i ; i=1 ; \ldots 5$; and $\mathrm{e}_{i j}=$ the residual experimental error. Least square means were compared using Tukey's method at $\alpha=0.05$.

\section{RESULTS}

There was no effect of lipid sources on $\mathrm{pH}(\mathrm{p}=0.533)$ and color measurements of longissimus muscle and subcutaneous fat (Table 2). The water-holding capacity ( $\mathrm{p}=$ $0.671)$ and sarcomere length $(\mathrm{p}=0.271)$ were not affected by lipid sources. However, differences were observed for WBSF ( $p=0.011)$ and cooking losses $(p=0.011)$ of beef from cattle fed different lipid sources. Beef from animals fed PO had greater values of shear force and cooking losses than beef from animals fed diets without addition of lipid source (Table 3).

With regard to fatty acid profile, with exception of C17:0 (margaric) in longissimus muscle and subcutaneous fat and C18:0 (stearic acid) in the subcutaneous fat, all the fatty acids were affected $(\mathrm{p}<0.05)$ by lipid sources (Table 4$)$. Animals fed PO had greater concentration of SFA C12:0 (lauric), C14:0 (myristic) and C15:0 (pentadecanoic) in both meat and subcutaneous fat $(\mathrm{p}<0.001)$.

The concentration of C16:0 (palmitic) was greater in meat of animals fed diets without addition of lipid source and lower in meat from animals fed LO $(\mathrm{p}<0.011)$. On the other hand, the lowest concentration of palmitic acid was observed in subcutaneous fat of animals fed LO $(\mathrm{p}<0.001)$. 
Table 2. Instrumental color evaluation of meat and subcutaneous fat, and final $\mathrm{pH}$ of confined Nellore steers fed diets with different lipid sources

\begin{tabular}{|c|c|c|c|c|c|c|c|}
\hline & \multicolumn{5}{|c|}{ Diets } & \multirow{2}{*}{ SEM } & \multirow{2}{*}{ p-value } \\
\hline & WF & PO & LO & $\mathrm{PF}$ & SG & & \\
\hline pH (24 h) & 5.73 & 5.79 & 5.76 & 5.77 & 5.73 & 0.29 & 0.533 \\
\hline \multicolumn{8}{|l|}{ Muscle $^{1}$} \\
\hline $\mathrm{L}$ & 39.3 & 39.3 & 39.3 & 41.1 & 39.4 & 0.82 & 0.331 \\
\hline$a^{*}$ & 15.9 & 16.1 & 16.0 & 15.9 & 14.9 & 0.41 & 0.231 \\
\hline $\mathrm{b}^{*}$ & 3.83 & 4.40 & 3.65 & 4.42 & 3.56 & 0.34 & 0.171 \\
\hline $\mathrm{H}$ & 13.4 & 14.9 & 12.8 & 15.3 & 13.4 & 0.87 & 0.141 \\
\hline $\mathrm{C}$ & 16.4 & 16.8 & 16.4 & 16.5 & 15.4 & 0.48 & 0.251 \\
\hline \multicolumn{8}{|c|}{ Subcutaneous fat } \\
\hline $\mathrm{L}$ & 72.8 & 74.3 & 74.0 & 73.8 & 68.7 & 1.68 & 0.101 \\
\hline $\mathrm{b}^{*}$ & 11.8 & 12.1 & 13.1 & 12.5 & 11.2 & 1.18 & 0.801 \\
\hline $\mathrm{h}$ & 83.7 & 85.0 & 88.3 & 82.5 & 78.3 & 2.75 & 0.131 \\
\hline $\mathrm{C}$ & 12.0 & 12.4 & 13.2 & 12.7 & 11.6 & 1.17 & 0.871 \\
\hline
\end{tabular}

WF, without additional fat; PO, palm oil; LO, linseed oil; PF, protected fat (LactoPlus); SG, soybean grains; SEM, standard error of the mean.

${ }^{1} \mathrm{~L}^{*}$, lighness; $\mathrm{a}^{*}$, redness; $\mathrm{b}^{*}$, yellowness; h, hue; $\mathrm{C}$, chroma.

The lowest concentration of C18:0 was observed in meat from animals fed diets without addition of lipid source when compared to diets containing PF and PO ( $\mathrm{p}=0.011)$. The addition of lipid sources reduced the concentration of oleic acid in meat $(\mathrm{p}<0.001)$. However, in subcutaneous fat the reduction in the oleic acid concentration was observed only in animals fed PO and PF $(\mathrm{p}<0.001)$.

A greater percentage of linoleic acid in the longissimus muscle and subcutaneous fat were observed in animals fed diets containing PF $(\mathrm{p}<0.001)$. The use of LO enhanced the concentration of alpha-linolenic acid and conjugated linoleic acid (CLA) $(18: 2 c 9, t 11)$ in longissimus muscle and subcutaneous fat $(\mathrm{p}<0.011)$.

Animals fed PO and PF had greater concentrations of SFA in longissimus muscle $(\mathrm{p}<0.001$; Table 5). A greater concentration of SFA in subcutaneous fat was observed in animals fed diets containing PO. The concentration of MUFA in both longissimus muscle and subcutaneous fat was lower for animals fed diets containing $\mathrm{PO}$ and $\mathrm{PF}$ $(\mathrm{p}<0.001)$.

Cattle fed PF had the greatest concentration of polyunsaturated fatty acids (PUFA) being similar to those observed for animals fed LO and soybean oil for longissimus muscle composition $(\mathrm{p}<0.011)$, and LO for composition of subcutaneous fat. The concentrations of UFA and the UFA:SFA ratio were lower in longissimus muscle and subcutaneous fat of animals fed PO and did not differ from longissimus muscle of animals fed $\mathrm{PF}$

Longissimus muscle and subcutaneous fat from animals fed diets containing PF had greater PUFA:SFA ratio than those fed diets containing PO. However, similar values of PUFA:SFA ratio was observed in subcutaneous fat of animals fed diets containing PF and LO.

Longissimus muscle and subcutaneous fat from animals fed diets containing PF and LO had greater values of total trans 18 fatty acids $(\mathrm{p}<0.011)$. A greater amount $\mathrm{f}$ total cis 18 fatty acids was observed on longissimus muscle and subcutaneous fat of animals fed diets without addition of lipid source, LO and soybean grains $(\mathrm{p}<0.001)$.

A greater concentration of fatty acids of $\omega-6$ family was observed on muscle and subcutaneous fat of cattle fed PF $(\mathrm{p}<0.001)$. The addition of LO in the diet increased the concentration of fatty acids from $\omega-3$ family in muscle ans subcutaneous fat.

The $\mathrm{C} 16$ and $\mathrm{C} 18 \Delta^{9}$-desaturase activity was greater in longissimus muscle from animals fed diets without addition of lipid source and lower in longissimus muscle of animals fed diets with PF $(\mathrm{p}<0.011)$. The activity of $\mathrm{C} 18 \Delta^{9}$ -

Table 3. Water holding capacity (WHC), sarcomere length (SL), Warner-Bratzler shear force (WBSF), and cooking losses (CL) of longissimus muscle from confined Nellore steers fed diets with different lipid sources

\begin{tabular}{lccccccc}
\hline & \multicolumn{9}{c}{ Diets $^{1}$} & \multirow{2}{*}{ SEM } & p-value \\
\cline { 2 - 5 } & WF & PO & LO & PF & SG & & 0.671 \\
WHC $(\mathrm{g} / 100 \mathrm{~g})$ & 68.1 & 67.1 & 68.2 & 66.2 & 67.9 & 1.17 & 0.271 \\
$\mathrm{SL}(\mu \mathrm{m})$ & 1.80 & 1.69 & 1.71 & 1.73 & 1.74 & 0.04 & 0.38 \\
WBSF $\left(\mathrm{kg} / \mathrm{cm}^{2}\right)$ & $4.14^{\mathrm{b}}$ & $5.87^{\mathrm{a}}$ & $4.70^{\mathrm{ab}}$ & $5.44^{\mathrm{ab}}$ & $5.26^{\mathrm{ab}}$ & 0.011 & 0.011 \\
CL $(\mathrm{g} / 100 \mathrm{~g})$ & $24.1^{\mathrm{b}}$ & $27.2^{\mathrm{ab}}$ & $25.3^{\mathrm{ab}}$ & $26.9^{\mathrm{a}}$ & $26.8^{\mathrm{a}}$ & 1.01 & 0.011 \\
\hline
\end{tabular}

WF, without additional fat; PO, palm oil; LO, linseed oil; PF, protected fat (LactoPlus); SG, soybean grains; SEM, standard error of the mean.

${ }^{\mathrm{a}, \mathrm{b}}$ Means within a row lacking the common superscript letter differ by Tukey's test at $\alpha=0.05$. 
Table 4. Main fatty acids ( $\mathrm{g} / 100 \mathrm{~g}$ of total fatty acids) of longissimus muscle and subcutaneous fat from confined Nellore steers fed diets with different lipid sources

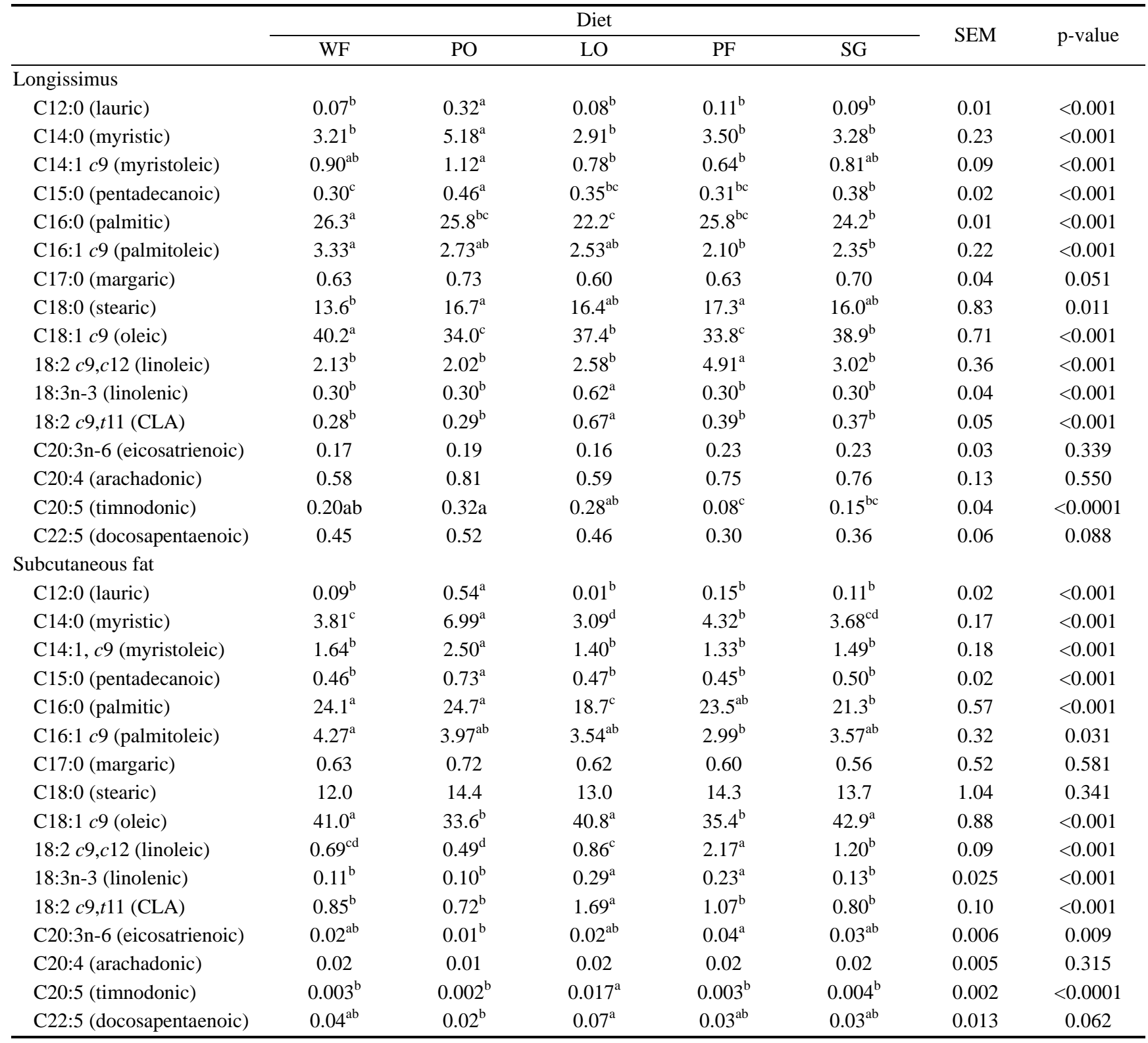

WF, without additional fat; PO, palm oil; LO, linseed oil; PF, protected fat (LactoPlus); SG, soybean grains; SEM, standard error of the mean. a,b,c,d Means within a row lacking the common superscript letter differ by Tukey's test at $\alpha=0.05$.

desaturase in muscle of animals fed PO was lower when compared to the muscle of animals that did not receive lipid supplementation. A greater activity of C16 $\Delta^{9}$-desaturase was observed in tissues of animals fed diets with LO compared to the tissues of animals fed diets with PF ( $\mathrm{p}=$ 0.031). On the other hand, the C18 $\Delta^{9}$-desaturase activity was greater in subcutaneous tisse of animals fed diets without addition of lipids compared to those fed diets with PO and PF ( $\mathrm{p}=0.011$; Table 6).

A lower atherogenicity index was observed in longissimus muscle and subcutaneous fat of animals fed diets containing LO $(\mathrm{p}<0.001)$. Animals fed LO and soybean grains had the greatest elongase activity in longissimus muscle and subcutaneous fat $(\mathrm{p}<0.001)$.

\section{DISCUSSION}

The $\mathrm{pH}$ values observed in the current study are within the normal $\mathrm{pH}$ range for beef (5.4 to 5.8) (Mach et al., 2008). The final $\mathrm{pH}$ is dependent on the acid lactic accumulation as a result of adenosine triphosphate production by using glycogen as a source of glucose (Oliveira et al., 2011). In general, cattle fed grain based diets have greater availability of glycogen at slaughter and lower ultimate $\mathrm{pH}$ of meat (Neath et al., 2007). Final pH values suggests that there was no pre-slaughter stress since 
Table 5. Main fatty acids (g/100 g of total fatty acids) of longissimus muscle and subcutaneous fat from confined Nellore steers fed diets with different lipid sources

\begin{tabular}{|c|c|c|c|c|c|c|c|}
\hline & \multicolumn{5}{|c|}{ Diets } & \multirow{2}{*}{ SEM } & \multirow{2}{*}{ p-value } \\
\hline & WF & $\mathrm{PO}$ & $\mathrm{LO}$ & $\mathrm{PF}$ & SG & & \\
\hline \multicolumn{8}{|l|}{ Longissimus } \\
\hline $\mathrm{SFA}^{1}$ & $45.5^{\mathrm{bc}}$ & $50.8^{\mathrm{a}}$ & $44.0^{\mathrm{c}}$ & $49.0^{\mathrm{ab}}$ & $46.1^{\mathrm{bc}}$ & 0.99 & $<0.001$ \\
\hline MUFA $^{2}$ & $48.4^{\mathrm{a}}$ & $42.2^{\mathrm{b}}$ & $48.1^{\mathrm{a}}$ & $42.5^{\mathrm{b}}$ & $46.6^{\mathrm{a}}$ & 0.88 & $<0.001$ \\
\hline PUFA $^{3}$ & $3.94^{\mathrm{b}}$ & $4.37^{\mathrm{b}}$ & $5.03^{\mathrm{ab}}$ & $6.85^{\mathrm{a}}$ & $5.07^{\mathrm{ab}}$ & 0.61 & 0.006 \\
\hline $\mathrm{UFA}^{4}$ & $52.4^{\mathrm{ab}}$ & $46.6^{c}$ & $53.2^{\mathrm{a}}$ & $49.4^{\mathrm{bc}}$ & $51.7^{\mathrm{ab}}$ & 1.00 & $<0.001$ \\
\hline UFA:SFA & $1.15^{\mathrm{ab}}$ & $0.92^{\mathrm{c}}$ & $1.22^{\mathrm{a}}$ & $1.01^{\mathrm{bc}}$ & $1.13^{\mathrm{ab}}$ & 0.05 & $<0.001$ \\
\hline PUFA:SFA & $0.09^{\mathrm{ab}}$ & $0.08^{\mathrm{b}}$ & $0.12^{\mathrm{ab}}$ & $0.14^{\mathrm{a}}$ & $0.11^{\mathrm{ab}}$ & 0.02 & 0.021 \\
\hline Total FA Cis $18^{5}$ & $45.6^{\mathrm{a}}$ & $38.8^{\mathrm{c}}$ & $43.8^{\mathrm{ab}}$ & $41.7^{\mathrm{bc}}$ & $45.2^{\mathrm{a}}$ & 0.86 & $<0.001$ \\
\hline Total FA Trans $18^{6}$ & $3.49^{\mathrm{b}}$ & $4.53^{\mathrm{b}}$ & $7.46^{\mathrm{a}}$ & $8.68^{\mathrm{a}}$ & $5.01^{\mathrm{b}}$ & 0.44 & $<0.001$ \\
\hline$\omega-6^{7}$ & $2.39^{\mathrm{b}}$ & $2.33^{\mathrm{b}}$ & $2.98^{\mathrm{b}}$ & $5.26^{\mathrm{a}}$ & $3.38^{\mathrm{b}}$ & 0.39 & $<0.001$ \\
\hline$\omega-3^{8}$ & $0.50^{\mathrm{b}}$ & $0.62^{\mathrm{b}}$ & $0.91^{\mathrm{a}}$ & $0.38^{\mathrm{b}}$ & $0.45^{\mathrm{b}}$ & 0.07 & $<0.001$ \\
\hline$\omega-6: \omega-3$ & $4.72^{\mathrm{c}}$ & $3.94^{c}$ & $3.27^{\mathrm{c}}$ & $13.8^{\mathrm{a}}$ & $7.53^{\mathrm{b}}$ & 0.74 & $<0.001$ \\
\hline \multicolumn{8}{|l|}{ Subcutaneous fat } \\
\hline SFA & $43.6^{\mathrm{b}}$ & $51.3^{\mathrm{a}}$ & $38.2^{\mathrm{c}}$ & $45.4^{\mathrm{b}}$ & $42.2^{\mathrm{bc}}$ & 1.23 & $<0.001$ \\
\hline MUFA & $51.8^{\mathrm{a}}$ & $43.7^{\mathrm{b}}$ & $55.2^{\mathrm{a}}$ & $48.5^{\mathrm{b}}$ & $53.1^{\mathrm{a}}$ & 0.99 & $<0.001$ \\
\hline PUFA & $1.78^{\mathrm{bc}}$ & $1.42^{\mathrm{c}}$ & $3.12^{\mathrm{a}}$ & $3.60^{\mathrm{a}}$ & $2.30^{\mathrm{b}}$ & 0.18 & $<0.001$ \\
\hline UFA & $53.6^{\mathrm{b}}$ & $45.1^{\mathrm{c}}$ & $58.3^{\mathrm{a}}$ & $52.1^{\mathrm{b}}$ & $55.4^{\mathrm{ab}}$ & 1.09 & $<0.001$ \\
\hline UFA:SFA & $1.24^{\mathrm{b}}$ & $0.89^{c}$ & $1.54^{\mathrm{a}}$ & $1.16^{\mathrm{b}}$ & $1.32^{\mathrm{b}}$ & 0.06 & $<0.001$ \\
\hline PUFA:SFA & $0.04^{\mathrm{bc}}$ & $0.03^{\mathrm{c}}$ & $0.08^{\mathrm{a}}$ & $0.08^{\mathrm{a}}$ & $0.06^{\mathrm{b}}$ & 0.01 & $<0.001$ \\
\hline Total FA Cis 18 & $45.1^{\mathrm{a}}$ & $36.7^{\mathrm{c}}$ & $46.3^{\mathrm{a}}$ & $40.8^{\mathrm{b}}$ & $47.9^{\mathrm{a}}$ & 0.94 & $<0.001$ \\
\hline Total FA Trans 18 & $3.91^{\mathrm{b}}$ & $4.22^{\mathrm{b}}$ & $8.65^{\mathrm{a}}$ & $9.91^{\mathrm{a}}$ & $4.26^{\mathrm{b}}$ & 0.42 & $<0.001$ \\
\hline$\omega-6$ & $0.86^{\mathrm{c}}$ & $0.67^{\mathrm{c}}$ & $1.31^{\mathrm{b}}$ & $2.43^{\mathrm{a}}$ & $1.43^{\mathrm{b}}$ & 0.10 & $<0.001$ \\
\hline$\omega-3$ & $0.12^{\mathrm{b}}$ & $0.11^{\mathrm{b}}$ & $0.32^{\mathrm{a}}$ & $0.21^{\mathrm{b}}$ & $0.13^{\mathrm{b}}$ & 0.03 & $<0.001$ \\
\hline$\omega-6: \omega-3$ & $8.63^{\mathrm{b}}$ & $6.89^{\mathrm{bc}}$ & $4.50^{\mathrm{c}}$ & $10.9^{\mathrm{ab}}$ & $12.2^{\mathrm{a}}$ & 1.25 & $<0.001$ \\
\hline
\end{tabular}

WF, without additional fat; PO, palm oil; LO, linseed oil; PF, protected fat (LactoPlus); SG, soybean grains; SEM, standard error of the mean; SFA, saturated fatty acids; MUFA, monosaturated fatty acids; PUFA, polysaturated fatty acids; UFA, unsaturated fatty acids.

${ }^{1}$ C4:0; C6:0; C8:0; C10:0; C12:0; C13:0iso; C13:0ant; C14:0iso; C14:0; C15:0iso; C15:0ant; C14:1c9; C15:0; C16:0iso; C16:0; C17:0iso; C17:0; C18:0; $\mathrm{C} 20: 0 ; \mathrm{C} 22: 0 ; \mathrm{C} 24: 0$.

${ }^{2} \mathrm{C} 16: 1 c 9$; C17:1; C18:1t6; C18:1t9; C18:1t10; C18:1t11; C18:1t12; C18:1c9; C18:1c11; C18:1c12; C18:1c13; C18:1t16; C18:1c15; C20:1; C22:1; $\mathrm{C} 24: 1$.

${ }^{3} \mathrm{C} 18: 2 t 11, c 15 ; \mathrm{C} 18: 2 c 9, c 12 ; \mathrm{C} 18: 3 ; \mathrm{C} 18: 2 c 9, t 11 ; \mathrm{C} 20: 3 ; \mathrm{C} 20: 4 ; \mathrm{C} 22: 2 ; \mathrm{C} 20: 5 ; \mathrm{C} 22: 5 ; \mathrm{C} 22: 6$.

${ }^{4}$ UFA $=$ MUFA+PUFA.

${ }^{5}$ Total fatty acids $c i s 18=\mathrm{C} 18: 1 c 9 ; \mathrm{C} 18: 1 c 11 ; \mathrm{C} 18: 1 c 12 ; \mathrm{C} 18: 1 c 13 ; \mathrm{C} 18: 1 c 15 ; \mathrm{C} 18: 2 t 11, c 15 ; \mathrm{C} 18: 2 c 9 c 12$.

${ }^{6}$ Total fatty acids trans $18=\mathrm{C} 18: 1 t 9, \mathrm{C} 18: 1 t 10 ; \mathrm{C} 18: 1 t 11 ; \mathrm{C} 18: 1 t 12 ; \mathrm{C} 18: 1 t 16 ; \mathrm{C} 18: 1 t 18 ; \mathrm{C} 18: 2 t 11, c 15 ; \mathrm{C} 18: 2 c 9, c 12$.

${ }^{7} \omega-6$, Omega- 6 fatty acids $=\mathrm{C} 18: 3 \mathrm{n}-6+\mathrm{C} 20: 3 \mathrm{n}-6+\mathrm{C} 18: 2 c 9, c 12+\mathrm{C} 18: 2 t 11, c 15$.

${ }^{8} \omega-3$, Omega- 3 fatty acids $=\mathrm{C} 18: 3 n-3+\mathrm{C} 20: 3 n-3+\mathrm{C} 20: 5 n-3$.

${ }^{\mathrm{a}, \mathrm{b}, \mathrm{c}}$ Means within a row lacking the common superscript letter differ by Tukey's test at $\alpha=0.05$.

muscle acidification has occurred as expected, and that final $\mathrm{pH}$ was not altered by the lipid sources evaluated. According to Fernandes et al. (2008) the beef industry in Brazil only exports meat with $\mathrm{pH}$ values lower than 5.8, evaluated $24 \mathrm{~h}$ postmortem directly on longissimus muscle.

The lack of effects of lipid sources on beef color may have occurred as a consequence of the lack of differences on $\mathrm{pH}$ values. The color of meat and fat is an important trait that influences the consumer's choice at purchase (Page et al., 2001). Muchenje et al. (2009) reported the following ranges for $L^{*}, a^{*}$, and $b^{*}$ values in beef: 33 to $41,11.1$ to 23.6 , and 6.1 to 11.3 , respectively. In the current study the values of $b^{*}$ were lower than those values. Oliveira et al. (2012) in a study with inclusion of soybean oil, LO, and calcium salt of soybean and LO in diets of confined young Nellore steers reported similar average values of those observed in the present study $\left(L^{*}=38.3 ; a^{*}=16.8 ; b^{*}=\right.$ 6.46) probably because the similarity of the animals used in both studies which had the same age and same breed.

The cold shortening may decrease meat tenderness and thus compromises its quality (Savell et al., 2005). According to Bouton et al. (1973), WBSF decreases exponentially as the sarcomere length increases but this correlation significant only for length lower than $2.0 \mu \mathrm{m}$. In the present study the average value of sarcomere length was $1.74 \mu \mathrm{m}$. However, the sarcomere length did not affect the WBSF of longissimus muscle.

Animals fed WF diet had lower values of cooking losses 
Table 6. Index of enzymes involved on fatty acids metabolism, atherogenicity and elongase index in longissimus muscle and subcutaneous fat from confined Nellore steers fed diets with different lipid sources

\begin{tabular}{|c|c|c|c|c|c|c|c|}
\hline & \multicolumn{5}{|c|}{ Diets } & \multirow{2}{*}{ SEM } & \multirow{2}{*}{ p-value } \\
\hline & WF & $\mathrm{PO}$ & LO & $\mathrm{PF}$ & SG & & \\
\hline \multicolumn{8}{|l|}{ Longissimus } \\
\hline Index of $\Delta^{9}$-desaturase $\mathrm{C} 16^{1}$ & $11.2^{\mathrm{a}}$ & $9.55^{\mathrm{ab}}$ & $10.2^{\mathrm{ab}}$ & $7.53^{\mathrm{b}}$ & $8.78^{\mathrm{ab}}$ & 0.81 & 0.011 \\
\hline Index of $\Delta^{9}$-desaturase $\mathrm{C} 18^{2}$ & $74.7^{\mathrm{a}}$ & $67.0^{\mathrm{b}}$ & $69.8^{\mathrm{ab}}$ & $66.1^{\mathrm{b}}$ & $70.9^{\mathrm{ab}}$ & 1.36 & $<0.001$ \\
\hline Elongase inde ${ }^{3}$ & $64.5^{\mathrm{b}}$ & $64.0^{\mathrm{b}}$ & $68.5^{\mathrm{a}}$ & $64.7^{\mathrm{b}}$ & $67.4^{\mathrm{a}}$ & 0.65 & $<0.001$ \\
\hline Atherogenicity index ${ }^{4}$ & $0.79^{\mathrm{ab}}$ & $0.85^{\mathrm{a}}$ & $0.69^{c}$ & $0.72^{\mathrm{b}}$ & $0.73^{\mathrm{b}}$ & 0.07 & $<0.001$ \\
\hline \multicolumn{8}{|l|}{ Subcutaneous fat } \\
\hline Index of $\Delta^{9}$-desaturase C16 & $15.0^{\mathrm{ab}}$ & $13.4^{\mathrm{ab}}$ & $15.8^{\mathrm{a}}$ & $11.3^{\mathrm{b}}$ & $14.2^{\mathrm{ab}}$ & 1.06 & 0.021 \\
\hline Index of $\Delta^{9}$-desaturase C18 & $77.4^{\mathrm{a}}$ & $70.1^{\mathrm{b}}$ & $75.9^{\mathrm{ab}}$ & $71.3^{\mathrm{b}}$ & $75.8^{\mathrm{ab}}$ & 1.08 & 0.011 \\
\hline Elongase index & $65.1^{\mathrm{b}}$ & $62.6^{\mathrm{b}}$ & $70.7^{\mathrm{a}}$ & $65.2^{\mathrm{b}}$ & $69.5^{\mathrm{a}}$ & 0.80 & $<0.001$ \\
\hline Atherogenicity index & $0.87^{\mathrm{b}}$ & $1.01^{\mathrm{a}}$ & $0.76^{\mathrm{c}}$ & $0.84^{\mathrm{b}}$ & $0.81^{\mathrm{b}}$ & 0.02 & $<0.001$ \\
\hline
\end{tabular}

WF, without additional fat; PO, palm oil; LO, linseed oil; PF, protected fat (LactoPlus); SG, soybean grains; SEM, standard error of the mean; SFA, saturated fatty acids; PUFA, polysaturated fatty acids.

${ }^{1}$ Index of $\Delta^{9}$-desaturase C16 activity $=100[(16: 1$ cis-9)/16:1 cis-9+16:0)].

${ }^{2}$ Index of $\Delta^{9}$-desaturase $\mathrm{C} 18$ activity $=100[(18: 1$ cis-9)/18:1 cis- $9+18: 0)]$.

${ }^{3}$ Elongase $=100[(\mathrm{C} 18: 0+\mathrm{C} 18: 1$ cis-9) $/(\mathrm{C} 16: 0+\mathrm{C} 16: 1$ cis-9+C18:0+C18:1 cis-9)].

${ }^{4}$ Atherogenicity index $=[\mathrm{C} 12: 0+4(14: 0)+\mathrm{C} 16: 0] /($ SFA + EPUFA $)$.

${ }^{\mathrm{a}, \mathrm{b}, \mathrm{c}} \mathrm{c}$ Means within a row lacking the common superscript letter differ by Tukey's test at $\alpha=0.05$.

which was the main factor that affect meat WBSF observed for these animals. According to Belew et al. (2003) meat is considered extremely tender when shear force values is lower than $3.2 \mathrm{~kg} / \mathrm{cm}^{2}$; tender when WBSF values are within 3.2 and $3.9 \mathrm{~kg} / \mathrm{cm}^{2}$; intermediate tenderness when WBSF values are within 3.9 and $4.6 \mathrm{~kg} / \mathrm{cm}^{2}$, and tough when WBSF values are greater than $4.6 \mathrm{~kg} / \mathrm{cm}^{2}$. Therefore, in the current study only animals fed diets without addition of lipid sources can be classified as "intermediate tenderness" while meat from the animals fed the other diets can be classified as "tough". Oliveira et al. (2012) did not find effect of supplementation with lipid source on WBSF of meat from confined young Nellore steers and reported values slightly higher $\left(5.97 \mathrm{~kg} / \mathrm{cm}^{2}\right)$ than those found the current study.

Another factor that may have contributed to the high values of WBSF observed in this study is the use of Bos indicus animals. It is well documented that the mean WBSF and variation in shear force increases as the percentage of Bos indicus, such as Nellore, inheritance increases (Lage et al., 2012). This is due to the fact that a greater calpastatin activity is commonly observed in Zebu cattle, which inhibits calpain activity leading to a less tenderization of beef (Curi et al., 2009).

The higher concentration of saturated fatty acids in animals fed PO was likely due to the saturated fatty acid profile of this lipid source compared to the other diets (Table 1). As reported by Scollan et al. (2006), the most saturated fatty acids found in beef are C14:0, C16:0, C18:0 (stearic), and the C18:0 represents approximately 30\% of the total saturated fatty acids. Among these fatty acids, the myristic and palmitic acids are of importance as they are considered hypercholesteromic (Wood et al., 2003). As reported by Oliveira et al. (2012), the concentration of C14:0 has a potential four times greater than C16:0 to increase the plasmatic concentration of cholesterol.

There is a correlation among C18 $\Delta^{9}$-desaturase and the concentration of oleic acid (Oliveira et al., 2011), which was confirmed in the current study as a highest concentration of oleic acid was observed in animals fed diets without addition of lipid source and lowest concentration was observed in animals fed diets with PO and PF. The greater concentration of linolenic acid in animals fed diets with PF was due to the greater level of this acid in the diet (Table 1). As the PF is partially inert in the ruminal environment, less biohydrogenation is observed in these acids in the rumen (Fiorentini, 2013). Consequently, a greater deposition of linoleic acid may occur in muscle and subcutaneous fat. Regarding the higher concentration of linolenic acid in muscle of animals fed LO and PF, it can be attributed to the greater amount of this acid in the diet which lead to a greater intake of this acid by the animals.

The diet with LO increased the levels of CLA (18:2 c9 t11) in muscle and subcutaneous fat being in accordance with results previously reported by Oliveira et al. (2012) who observed values of CLA $(0.72 \mathrm{~g} / 100 \mathrm{~g})$ close to those found in the present study $(0.67 \mathrm{~g} / 100 \mathrm{~g})$. The increase of CLA amount in the carcass of animals fed LO is due to the amount of linolenic acid found in such source (Table 1). Before the biohydrogenation, the triglycerides that reach the ruminal environment are hydrolyzed into fatty acids and glycerol. During the biohydrogenation process, isomeriation reactions convert cis bounds into trans bounds before the beginning of the reduction reactions which add hydrogen to 
the double bounds. However, not all the UFA that reach the ruminal environment are biohydrogenated in this process and part of the intermediate UFA with trans bounds flows to the duodenum and then deposited in the tissues (Duckett and Gillis, 2010). Thus, a greater amount of intermediate fatty acids escapes from the ruminal biohydrogenation as the dietary substrates for biohydrogenation (C18:2 and C18:3) increases, leading to an enhancement of CLA accumulation in the carcass.

Besides the CLA that escapes the ruminal biohydrogenation, the vaccenic acid (trans $\mathrm{C} 18: 1$ ) may also be converted into CLA in the adipose and muscle tissues though the activity of desaturase enzyme $\left(\mathrm{C} 18-\Delta^{9}\right)$ in both animals and humans. Diets with a potential to elevate the concentration of CLA such as soybean grains (slow released of oil in the rumen), likely did not released enough amounts of linoleic or linolenic acids for biohydrogenation, as reported by Nelson et al. (2008) in a study with vegetal oil.

The C16 $\Delta^{9}$-desaturase is responsible for the desaturation of saturated fatty acids with 16 and 18 carbons and their conversion into their correspondent monounsaturated with a double bound on carbon 9. This was observed in the present study since diets with PF had lower concentration of MUFA. The different level of palmitoleic acid found in the longissimus muscle was due to the activity of C16 $\Delta^{9}$-desaturase which is responsible for the conversion of palmitic into palmitoleic acid (Oliveira et al., 2011).

A greater intake of MUFA is beneficial to human health as it decreases the levels of plasmatic total cholesterol (Department of Health of London, 1994). In the present study it is represented by animals fed diets without addition of lipid source, LO and soybean grains, likely due to the combination of lipid profile of the diets in association of the ingestion of these acids.

According to Sanhueza et al. (2002), differently than UFA cis, the trans fatty acids have on the hydrogen molecules of their double bound in a transversal disposition being a result of ruminal biohydrogenation or from industrial process. The general concept of trans fatty acids refers to a nonbeneficial effects on human health with blood lipid effects, inhibition of hepatic enzymes, challenge on fluidity of cell membrane, and arteriogenic potential, with exception of the endogenous precursor of CLA, the CLA and its isomers which have benefic effects related to immunoestimulating, antimutagenesis, and antioxidant activities (Ip, 1997). Muscle of animals fed LO and PF had higher concentration of trans fatty acids likely due to the combination of composition and diet intake. However, besides this observation, it cannot be affirmed that theses lipid sources should not be used because of its nonbeneficial effects since the composition of other fatty acids must be evaluated.

The LO had the lowest atherogenicity index, showing a great potential to improve the quality of meat and subcutaneous fat. This is an important trait as it is related to pro and anti-atherogenic acids and indicates the potential stimuli to platelets aggregation. Therefore the amount of anti-atheorgenic fatty acids in the subcutaneous fat is increased by the enhancement of the atherogenicity index. Consequently, there is a greater potential to prevent the occurrence of coronary artery diseases (Ulbricht and Southgate, 1991).

According to Lopes et al. (2012) there is a correlation among the concentration of palmitic acid, palmitoleic acid and enhancement of oleic acid. Thus, the higher activity of elongase enzyme observed in animals fed LO and soybean grains may be explained by a lower concentration of palmitic and palmitoleic acids in addition to a greater amount of oleic acid. According to Smith et al. (1995), elongase enzyme has higher activity in adipose than muscle tissue, which was not observed in the present study.

The fatty acids from $\omega-3$ and $\omega-6$ families are essential for humans as it has not an endogenous synthesis. Thus, the $\omega-3$ intake is encouraged and the $\omega-6: \omega-3$ ratio is recommended to be lower than 4:1 (Wood et al., 2003), and higher values may indicate a non-healthy diet that may lead to a coronary artery diseases (Department of Health of London, 1994). The $\omega-6: \omega-3$ ratio observed in meat of animals fed diets without addition of lipid sources, with palm or LO was closer of the recommended value. Conversely, the values of $\omega-6: \omega-3$ ration observed in the subcutaneous fat were higher than the recommended values (4:1) for all treatments.

\section{CONCLUSION}

The addition of lipid sources in finishing diets of confined young steers alters longissimus muscle quality the profile of fatty acids. The inclusion of LO in the diet enhances the concentration of CLA in longissimus muscle and subcutaneous fat besides the improvement of atherogenicity index and elongase activity. As such, LO can be used with the aim to improve the quality of beef from confined Nellore cattle. Conversely, the use of PO is not recommended since it may increase the concentration of undesirable UFA in muscle and subcutaneous fat, shearforce and the atherogenicity index.

\section{ACKNOWLEDGMENTS}

We thank the São Paulo Research Foundation (FAPESP) (grants \#2009/ 51215-1 and 2009/ 06472-6) and Bellman Nutrição Animal for providing financial support. We thank 
all of the participants for their help in the study. Giovani Fiorentini is the main author. Study is a part of my doctoral thesis. I participated in all the processes of the study, from designing to conducting the experiment, laboratory analysis, statistical analysis and drafted the manuscript. Josiane F. Lage and Isabela P. C. Carvalho, are doctoral colleagues which had their thesis from the same experiment. They participated in the study design, in the conduction of the experiment and laboratory analyzes. Juliana D. Messana and Roberta C. Canesin, are post-doctoral at the São Paulo State University who interpretation of data, the drafting the article or revising it critically for important intellectual content. Ricardo A. Reis is teacher and research in School of Agricultural Sciences. Participated in planning the study as co-advisor and assisted discussion of the results. Telma T. Berchielli is my advisor of my thesis. She participated in the study design, statistical analysis and discussion of the results. The authors declare that there is no conflict of interests.

\section{REFERENCES}

Allen, M. S. 2000. Effects of diet on short-term regulation of feed intake by lactating dairy cattle. J. Dairy Sci. 83:1598-1624.

AMSA (American Meat Science Association). 1995. Research guidelines for cookery, sensory evaluation and tenderness measurements of fresh meat. Chicago: National Livestock and Meat Board, IL, USA.

AOAC. 1990. Official Methods of Analysis. 15th edn. Association of Official Analytical Chemists, Arlington, VA, USA.

Belew, J. B., J. C. Brooks, D. R. McKenna, and J. W. Savell. 2003. Warner-Bratzler shear evaluations of 40 bovine muscles. Meat Sci. 64:507-512.

Bligh, E. G. and W. J. Dyer. 1959. A rapid method of total lipid extraction and purification. Can. J. Biochem. Physiol. 37:911917.

Bouton, P. E., A. L. Fisher, P. V. Harris, and R. I. Baxter. 1973. A comparison of the effects of some post-slaughter treatments on the tenderness of beef. Int. J. Food Sci. Technol. 8:39-49.

Cross, H. R., R. L. West, and T. R. Dutson. 1981. Comparison of methods for measuring sarcomere length in beef semitendinosus muscle. Meat Sci. 5:261-266.

Curi, R. A., L. A. L. Chardulo, M. C. Mason, M. D. B. Arrigoni, A. C. Silveira, and H. N. de Oliveira. 2009. Effect of single nucleotide polymorphisms of CAPN1 and CAST genes on meat traits in Nellore beef cattle (Bos indicus) and in their crosses with Bos taurus. Anim. Genet. 40:456-462.

Daley, C. A., A. Abbott, P. S. Doyle, G. A. Nader, and S. Larson. 2010. A review of fatty acid profiles and antioxidant content in grass-fed and grain-fed beef. Nutr. J. 9:10.

Department of Health. 1994. Nutritional Aspects of Cardiovascular Disease. Report on Health and Social Subjects No. 46, HSMO, London, UK.

Duckett, S. K. and M. H. Gillis. 2010. Effects of oil source and fish oil addition on ruminal biohydrogenation of fatty acids and conjugated linoleic acid formation in beef steers fed finishing diets. J. Anim. Sci. 88:2684-2691.

Fernandes, A. R. M., A. A. M. Sampaio, W. Henrique, E. A. Oliveira, R. R. Tullio, and D. Perecin. 2008. Carcass and meat characteristic of cattle receiving differents diets in feedlot. Arq. Bras. Med. Vet. Zootec. 60:139-147.

Fiorentini, G. 2013. Nellore Steers Finished in Feedlot with Differents Lipidic Sources. PhD Tesis, Universidade Estadual Paulista, Jaboticabal, Brazil.

Fiorentini, G., T. T. Berchielli, M. C. A. Santana, P. H. M. Dian, R. A. Reis, A. A. M. Sampaio, and M. V. Biehl. 2012. Qualitative characteristics of meat from confined crossbred heifers fed with lipid sources. Sci. Agric. 69:336-344.

Folch, J., M. Lees, and G. H. S. Stanley. 1957. A simple method for the isolation and purification of total lipids from animal tissues. J. Biol. Chem. 226:497-509.

Herdmann, A., K. Nuernberg, J. Martin, G. Nuernberg, and O. Doran. 2010. Effect of dietary fatty acids on expression of lipogenic enzymes and fatty acid profile in tissues of bulls. Animal 4:755-762.

Houben, J. H., A. van Dijk, G. Eikelenboom, and A. H. HovingBolink. 2000. Effect of dietary vitamin E supplementation, fat level and packaging on colour stability and lipid oxidation in minced beef. Meat Sci. 55:331-336.

Ip, C. 1997. Review of the effects of trans fatty acids, oleic acid, n-3 polyunsaturated fatty acids, and conjugated linoleic acid on mammary carcinogenesis in animals. Am. J. Clin. Nutr. 66: I523S-I529S

Jenkins, T. C. and W. C. Bridges Jr. 2007. Protection of fatty acids against ruminal biohydrogenation in cattle. Eur. J. Lipid Sci. Technol. 109:778-789.

Koolmees, P. A., F. Korteknie, and F. J. M. Smulders. 1986. Accuracy and utility of sarcomere length assessment by laser diffraction. Food Microstructure 5:71-76.

Kramer, J. K. G., V. Fellner, M. E. R. Dugan, F. D. Sauner, and M. M. Mossoba, and M. P. Yurawecz. 1997. Evaluating acid and base catalysts in the methylation of milk and rumen fatty acids with special emphasis conjugated dienes and total trans fatty acids. Lipids 32:1219-1228.

Ladeira, M. M., L. C. Santarosa, M. L. Chizzotti, E. M. Ramos, O. R. Machado Neto, D. M Oliveira, J. R. R. Carvalho, L. S. Lopes, and J. S. Ribeiro. 2014. Fatty acid profile, color and lipid oxidation of meat from young bulls fed ground soybean or rumen protected fat with or without monensin. Meat Sci. 96: 597-605.

Lage, J. F., P. V. R. Paulino, S. C. V. Filho, E. J. O. Souza, M. S. Duarte, P. D. B. Benedeti, N. K. P. Souza, and R. B. Cox. 2012 Influence of genetic type and level of concentrate in the finishing diet on carcass and meat quality traits in beef heifers. Meat Sci. 90:770-774.

Lopes, L. S., M. M. Ladeira, O. R. Machado Neto, E. M. Ramos, P. V. R. Paulino, M. L. Chizzotti, and M. C. Guerreiro. 2012. Chemical composition and of fatty acids of the muscle longissimus dorsi and backfat of Red Norte and young Nellore bulls. R. Bras. Zootec. 41:978-985.

MacDougall, D. B. 1994. Colour of meat. In: Quality Attributes and Their Measurement in Meat, Poultry and Fish Products (Eds. A. M. Pearson and T. R. Dutson). Advances in Meat Research Series 9. Blackie Academic and Professional, 
London, UK. pp. 79-93.

Mach, N., A. Bach, A. Velarde, and M. Devant. 2008. Association between animal, transportation, slaughterhouse practices, and meat $\mathrm{pH}$ in beef. Meat Sci. 78:232-238.

Malau-Aduli, A. E. O., B. D. Siebert, C. D. K. Bottema, and W. S. Pitchford. 1997. A comparison of the fatty acid composition of triacylglycerols in adipose tissue from Limousin and Jersey cattle. Aust. J. Agric. Res. 48:715-722.

Moloney, A. P., C. Kennedy, F. Noci, F. J. Monahan, and J. P. Kerry. 2012. Lipid and colour stability of M. longissimus muscle from lambs fed camelina or linseed as oil or seeds. Meat Sci. 92:1-7.

Muchenje, V., K. Dzama, M. Chimonyo, P. E. Strydom, and J. G. Raats. 2009. Some biochemical aspects pertaining to beef eating quality and consumer health: A review. Food Chem. 112:279-289.

Neath, K. E., A. N. Del Barrio, R. M. Lapitan, J. R. V. Herrera, L. C. Cruz, T. Fujihara, S. Muroya, K. Chikuni, M. Hirabayashi, and Y. Kanai. 2007. Difference in tenderness and $\mathrm{pH}$ decline between water buffalo meat and beef during postmortem aging. Meat Sci. 75:499-505.

Nelson, M. L., J. R. Busboom, C. F. Ross, and J. V. O'Fallon. 2008. Effects of supplemental fat on growth performance and quality of beef from steers fed corn finishing diets. J. Anim. Sci. 86:936-948.

National Research Council. 2000. Nutrient Requirements of Beef Cattle. National Academy Press. Washington, DC, USA.

National Research Council. 2001. Nutrient Requirements of Dairy Cattle. National Academy Press. Washington, DC, USA.
Oliveira, D. M., M. M. Ladeira, M. L. Chizzotti, O. R. Machado Neto, E. M. Ramos, T. M. Goncalves, M. S. Bassi, D. P. Lanna, and J. S. Ribeiro. 2011. Fatty acid profile and qualitative characteristics of meat from zebu steers fed with different oilseeds. J. Anim. Sci. 89: 2546-2555.

Oliveira, E. A., A. A. M. Sampaio, W. Henrique, T. M. Pivaro, B. L. Rosa, A. R. M. Fernandes, and A. T. Andrade. 2012. Quality traits and lipid composition of meat from Nellore young bulls fed with different oils either protected or unprotected from rumen degradation. Meat Sci. 90:28-35.

Page, J. K., D. M. Wulf, and T. R. Schwotzer. 2001. A survey of beef muscle color and pH. J. Anim. Sci. 79:678-687.

Sanhueza, J., S. Nieto, and A. Valenzuela. 2002. Conjugated linoleic acid: a trans isomer fatty acid potentially beneficial. Rev. Chil. Nutr. 29:98-105.

Savell, J. W., S. L. Mueller, and B. E. Baird. 2005. The chilling of carcasses. Meat Sci. 70:449-459.

Scollan, N., J. F. Hocquette, K. Nuernberg, D. Dannenberger, I. Richardson, and A. Moloney. 2006. Innovations in beef production systems that enhance the nutritional and health value of beef lipids and their relationship with meat quality. Meat Sci. 74:17-33.

Smith, G. C., J. W. Savell, H. G. Dolezal, T. G. Field, D. R. Gill, D. B. Griffin, D. S. Hale, J. B. Morgan, S. L. Northcutt, and J. D. Tatum. 1995. The final report of the national beef quality audit. National Cattleman's Association, Englewood, CO, USA.

Ulbricht, T. L. V. and D. A. T. Southgate. 1991. Coronary heart disease: Seven dietary factors. Lancet 338:985-992.

Wood, J. D., R. I. Richardson, G. R. Nute, A. V. Fisher, M. M. Campo, E. Kasapidou, P. R. Sheard, and M. Enser. 2003. Effects of fatty acids on meat quality: A review. Meat Sci. 66:21-32. 